\title{
Influence of Preharvest Sprays with Maleic Hydrazide on the Sprouting of Potatoes
}

\author{
Héctor Cỉbes, George Samuels, and Juan P. Rodriguez ${ }^{1}$ \\ INTRODUCTION
}

Although the potato (Solanum tuberosum L.) is not native to Puerto Rico, it is widely consumed in the Island. For the most part, it has been imported from the United. States. Though the potato can be grown here commercially, it has not been planted extensively because of disease problems (blights and virus diseases) and the premature sprouting of the seed potatoes before planting.

The disease problem has largely been solved by the use of the blightresistant variety Kennebec introduced into Puerto Rico by the Agricultural Experiment Station, Río Piedras (1). ${ }^{2}$ However, the premature sprouting of the tubers remains a serious problem because the proper seed pieces for planting cannot be maintained and fresh imports from the United States must be made annually.

Sprouting is also troublesome to the grocery storekeeper in that it causes loss of saleable tubers when potatoes are stored for any length of time before sale.

With these facts in mind research was initiated to determine whether any chemical treatment might be used to inhibit sprouting of potatoes in storage.

\section{PROCEDURE}

A field of the Kennebec variety of potato growing on a Vía clay at Aibonito was used to test the preharvest application of maleic hydrazide for determining its influence on the sprouting of potatoes in storage. Maleic hydrazide was applied at concentrations of $0.25,0.50$, and 1.00 percent in spray form on the potato foliage at intervals of 6,4 , and 2 weeks before harvesting the crop, beginning October 15, 1952. The plot-size used was 4 rows, $2 \frac{1}{2}$ feet apart and 20 feet long, or one two-hundred-eighteenth of an acre. Each plot was inclosed by portable plywood shields when being sprayed to prevent drifting of the spray material to adjacent plots.

Potato samples of 25 pounds each were obtained after harvest from the differently treated plots, placed in 50-pound open-weave fabric bags, and

${ }^{1}$ Associate Plant Physiologist, Agronomist, and Associate Agronomist, respectively, Agricultural Experiment Station, University of Puerto Rico, Río Piedras, P. R.

2 Numbers in parentheses refer to Literature Cited, p. 99. 
stored at temperatures of $45^{\circ}$ and $68^{\circ} \mathrm{F}$. in controlled cold storage chambers. The number of tubers which had sprouted was ascertained after 6 months storage.

\section{RESULTS}

The results on the influence of maleic hydrazide preharvest sprays on the yield and sprouting of the potato are given in table 1.

\section{EFFECTS ON YIELD AND SHAPE OF TUBERS}

The application of maleic hydrazide 6 weeks before harvesting the crop, and at any of the concentrations used, had a marked detrimental effect on the yields. The yield differences between these plots and plots similarly treated later in the growing season were highly significant. In fact, yields were reduced 71 percent when plots were sprayed 6 weeks before harvesttime as compared to 4 or 2 weeks.

The reduction in yield in these plots was apparently produced by a reduction in the size of the tubers. It was observed that a considerable number of the tubers were very small. Some of them were the size of a cherry. This condition bore some relation to the concentration of the maleic hydrazide used. Plants sprayed with a 1-percent solution usually produced tubers of smaller size than plants sprayed with a 0.5 -percent solution, and these, in turn, produced smaller tubers than those receiving a 0.25 -percent maleic hydrazide spray. This may explain why there was a tendency, within the above-mentioned time of treatment, for the yields to decrease somewhat with an increase in the concentration of the maleic hydrazide in the spray solution.

The various maleic hydrazide treatments applied 6 weeks before harvesttime not only affected the yields of the experimental plots, but also affected the shape of the tubers. Tubers harvested in these plots had protuberances all over their surface; there was also some cracking. The malformation was attributed to secondary growth.

Apparently the number of tubers set per plant under these various treatments was not affected. On the contrary, it was observed that the number of tubers was higher in plots which were sprayed with the highest concentration of the chemical than in plots treated otherwise. These were also the plots that produced the smallest potatoes.

According to the data presented in table 1 there were no significant differences in yields between potato plots treated 4 or 2 weeks before the crop was harvested, regardless of the concentration of the chemical used in the spray solution. No distortion in shape of the tubers could be detected at these two times, nor did the tubers exhibit any cracking; they also appeared to be of normal size. 
TABLE 1.-Influence of various concentrations of maleic hydrazide sprays, and time intervals of application, on the yields and sprouting of potatoes of the Kennebec variety when stored at $45^{\circ}$ and $68^{\circ} \mathrm{F}$.

\begin{tabular}{|c|c|c|c|c|}
\hline \multicolumn{2}{|c|}{ Treatments } & \multirow{2}{*}{$\begin{array}{l}\text { Yield of potatoes } \\
\text { per acre }\end{array}$} & \multicolumn{2}{|c|}{$\begin{array}{c}\text { Potatoes sprouted when } \\
\text { stored at }\end{array}$} \\
\hline $\begin{array}{c}\text { Time of application before } \\
\text { harvest (weeks) }\end{array}$ & $\begin{array}{l}\text { Concentration of maleic } \\
\text { hydrazide }\end{array}$ & & $45^{\circ} \mathrm{F}$ & $68^{\circ} \mathrm{F}$. \\
\hline \multirow{4}{*}{6} & Percent & Cwt. & Percent & Percent \\
\hline & 0.25 & 25.7 & 37 & 47 \\
\hline & .50 & 14.6 & 24 & 47 \\
\hline & 1.00 & 9.4 & 7 & 24 \\
\hline Mean .............. & & 16.6 & 23 & 39 \\
\hline \multirow[t]{3}{*}{4} & 0.25 & 56.0 & 6 & 27 \\
\hline & .50 & 60.4 & 15 & 46 \\
\hline & 1.00 & 57.3 & 19 & 36 \\
\hline Mean................ & & 57.8 & 13 & 36 \\
\hline \multirow[t]{3}{*}{2} & 0.25 & 61.0 & 33 & 55 \\
\hline & .50 & 56.0 & 38 & 58 \\
\hline & 1.0 & 56.0 & 30 & 45 \\
\hline \multicolumn{2}{|l|}{ Mean . . . . . . . . . } & 57.6 & 34 & 53 \\
\hline \multicolumn{2}{|l|}{0 (control) } & 79.6 & 48 & 75 \\
\hline \multicolumn{2}{|c|}{ Mean of all chemical treatments......... } & 44.0 & 23 & 43 \\
\hline \multicolumn{2}{|c|}{ Mean of all storage temperatures ......... } & - & 26 & 46 \\
\hline
\end{tabular}

Least significant difference needed between means of time of application treatments :

\begin{tabular}{l|l|l|l}
5 -percent level $\ldots \ldots \ldots \ldots \ldots \ldots \ldots \ldots \ldots$ & 16.6 & 25 & 25 \\
1 -percent level . . . & $23 \ldots \ldots \ldots \ldots \ldots \ldots$ & 40 & 40 \\
\hline
\end{tabular}

Least significant difference needed between means of all chemical treatments and control:

5-percent level

13.1

1-percent level

20.1

7
10

10

Least significant difference needed between means of 2 storage temperatures:

5 -percent level . . . . . . . . . . . . . . . . . . . . . . 10

1 -percent level . . . . . . . . . . . . . . . 13 
Table 1 also shows that plots treated with maleic hydrazide 4 or 2 weeks before the crop was harvested yielded significantly less at the 5-percent level than plots which received no chemical treatment at all. However, the differences between these same plots were not significant at the 1-percent level. This shows that although the detrimental effect of maleic hydrazide was considerably reduced by spraying late in the growing season, it was not completely compensated for by the late application.

\section{EFFECT ON GROWTH AND APPEARANCE OF PLANTS}

Maleic hydrazide also affected the growth and appearance of potato plants. Application of maleic hydrazide, regardless of the time of application and the concentration used, resulted in dieback of plants and development of a chlorotic condition. However, the time of application and the concentration of the chemical in the spray solution greatly modified the intensity and the extent of the injury. The higher the concentration of the maleic hydrazide and the earlier it was applied to the plants, the more severe the injury:

In general, the first abnormality to appear, 2 weeks after the plants were sprayed, was a chlorosis. The plants at first showed a slight discoloration. After some time they turned completely yellow. In severe cases, as when the plants were sprayed with the highest concentration 6 weeks prior to harvest, they showed severe dieback of the shoots and burning of the younger leaves. These plants tended to produce lateral shoots from the axillary buds below the injured portion; these new branches gave the plants a bushy appearance.

\section{EFFECT ON SPROUTING OF STORED TUBERS}

On the other hand, maleic hydrazide had a beneficial effect in preventing the sprouting of the tubers in storage. When, for example maleic hydrazide was applied at the rate of 1 percent 6 weeks before the harvest, sprouting was reduced significantly in storage. However, the fact that yields were so drastically reduced, and that the tubers were malformed, nullified the otherwise beneficial effect of the chemical treatment in preventing sprouting.

Application of maleic hydrazide at the various concentrations 2 weeks before harvesttime resulted in a high percentage of sprouted tubers at both temperatures. It seems probable that, at this stage of growth, so close to harvesting the crop, the absorption of maleic hydrazide through the leaves was too slow, and the time permitted for its absorption too short. Therefore, the commercial application of maleic hydrazide that late in the growing season is not warranted. 
The best results were- obtained from the sprout-inhibition standpoint when maleic hydrazide was applied 4 weeks before the end of the field. experiment. At this time of application the sprouting of tubers in storage was considerably reduced as compared to the control and other treatments. At this time of treatment a concentration of 0.25 percent of maleic hydrazide gave the best results. When stored at $45^{\circ} \mathrm{F}$. these tubers showed only 6 -percent sprouting and, at $68^{\circ} \mathrm{F}$., the sprouting was 27 percent.

Temperature itself had a marked effect on the sprouting of tubers. Regardless of the time of application or the concentration of maleic hydrazide solution used, the sprouting of potatoes was significantly lower in storage at $45^{\circ} \mathrm{F}$. than at $68^{\circ} \mathrm{F}$.

\section{DISCUSSION}

From the foregoing results it seems that yields of potatoes are more affected by the time at which maleic hydrazide is applied to the plant than by the concentration. Apparently maleic hydrazide should be applied when the tubers are all set and making good growth. Otherwise most of them will remain small and malformed.

Similar results have been obtained by other investigators with the potato and bulbous plants. Denisen (2), using the same Kennebec variety, found that yields declined drastically with increased concentration after a prebloom application. On the other hand, full-bloom sprays resulted in less decreased yield for the respective concentrations. The treatments applied at the bloom-drop stage gave no yield reduction at all.

Moreover, Barnard and Warden (3) found that 0.1-percent maleic hydrazide applied early in the season for the control of weeds in a potato plantation depressed yields by 12 percent, slightly increased tuber set, and reduced the size of the tubers. The use of 0.5-percent maleic hydrazide reduced yields by 83 percent, increased tuber set by 124 percent, and lowered the size of No. 1 potatoes 45 percent.

Furthermore, Wittwer and Paterson (4), working with onions, obtained similar results. Onion plants treated with maleic hydrazide too early in the season produced hollow or puffy bulbs. These authors recommended that onion plants should be treated when the bulbs had matured but still had green tops, usually 1 to 2 weeks before harvest.

Greulach (5) found marked differences in the growth of tomato plants sprayed with various concentrations of maleic hydrazide. He found that all plants treated when they were 3 weeks old had higher shoot:root ratios than the controls. The extremely high shoot:root ratio of the plants treated when 3 weeks old was particularly noteworthy.

In attempting to explain these differences in the shoot:root ratios he pointed out that the inhibition of root growth was caused by the inter- 
ference of maleic hydrazide with the translocation of food in the plants. This was indicated by: (1) The high water content of the roots, (2) the relatively low water content of the shoots of treated plants, (3) the fact that maleic hydrazide collapsed the phloem elements in cotton plants, (4) the extremely slow translocation of starch from the leaves of treated plants, and (5) reports of accumulation of food in the leaves of plants treated with maleic hydrazide.

It is possible that, as in the tomato and other woody plants, the application of maleic hydrazide to potato vines interferes with the translocation of food material to the roots. This may account for the small size of the tubers. It also may be possible that, at this early stage, absorption of maleic hydrazide by plants is so high, and its translocation to and concentration in the roots is such that it may interfere with the development of the tubers. It has been found that young plants and plants treated with maleic acid at the start of the growing season are more susceptible to maleic hydrazide than older plants or plants treated later in the growing season.

The time of application also interfered with the sprouting of the tubers in storage. The early and midseason applications controlled sprouting effectively when the tubers were stored at $45^{\circ} \mathrm{F}$.; the late application of the chemical had very little effect on sprouting. Wittwer and Paterson (4) made similar observations on Irish .Cobbler and Pontiac potato varieties when sprayed with 0.1 - to 0.25 -percent solutions of maleic hydrazide a few days to a week before harvest. Sprouting of stored tubers was not completely delayed under these treatments. However, vines sprayed with 0.1 percent displayed almost complete sprout inhibition if the spray wias applied when the tubers were immature and about 1 to 2 inches in diameter. This proved true even when the potatoes were stored at $55^{\circ} \mathrm{F}$.

Results similar to these have been obtained with hormonelike substances. Ellison and Smith (6) found that the methyl ester of naphthaleneacetic acid applied in July controlled sprouting better in storage than did later applications. August application reduced sprouting significantly as compared with the check. No sprouting inhibition was associated with September applications.

The statistical analyses of the data obtained in this experiment show that there was no significant relationship between reduction of yield and the various maleic hydrazide concentrations, when time of application was disregarded. However, the concentration apparently affected the sprouting of the tubers in storage, especially when at $45^{\circ} \mathrm{F}$. temperature.

When the application was made 6 weeks before harvesttime sprouting of tubers decreased as the concentration of the maleic hydrazide was increased. On the other hand, the reverse occurred when the various concentrations of the chemicals were sprayed on plants 4 weeks before they were 
harvested. In this particular case the extent of sprouting was directly proportional to the concentration of the maleic hydrazide used.

Maleic hydrazide can affect the morphology and other physiological changes in plants. Responses similar to those described for potato varieties in this paper have been observed by Mikkelsen, Griffith, and Ririe (7) in the sugar beet, and by Craft (8) in numerous other plants. The senior author has observed abnormal formative effects to be induced by maleic hydrazide in various tropical plants such as sugarcane, sweetpotato, yams, and tobacco.

\section{SUMMARY}

1. The application of maleic hydrazide 6 weeks before harvesting the crop at any one of the concentrations used-0.25, 0.50 , and 1 percent-had a marked detrimental effect on yields of potatoes. A considerable proportion of the tubers in these plots were small and malformed.

2. There were no significant differences in yields between potato plants treated 4 and 2 weeks before the crop was harvested.

3. Such plots yielded significantly less where sprayed at the 5-percent level than did the control plots.

4. Application of maleic hydrazide, regardless of time of application and concentration, resulted in dieback of plants and the development of a chlorotic condition.

5. The best results from the standpoint of sprout inhibition were obtained when 0.25-percent maleic hydrazide was applied to potato plots 4 weeks prior to harvesttime.

6. Regardless of time of application or concentration of the maleic hydrazide, the sprouting of potato tubers was significantly lower at $45^{\circ}$ than $68^{\circ} \mathrm{F}$.

\section{RESUMEN}

Los resultados de la aplicación de la hidrazina del ácido maleico y sus efectos sobre la germinación de la papa se informan como sigue:

1. Cuando se aplicó la hidrazina del ácido maleico, sin importar la concentración a que fué usiada, 6 semanas antes de la cosecha de papas, este compuesto químico turo efectos desventajosos sobre los rendimientos. Los tubérculos obtenidos de los predios tratados, en su gran mayoría fueron pequeños y deformes.

2. No hubo diferencias significativas entre los rendimientos de las plantas tratadas 4 y 2 semanas antes de efectuarse la cosecha. Sin embargo, al ampliar el análisis estadístico se vió que los predios tratados 4 y 2 semanas antes de la cosecha rindieron significativamente menos, al 5 porciento, que los predios sin tratar (check plots). 
3. Siempre que se aplicó la hidrazina del ácido meleico, sin importar la concentración usada, causó marchitez y clorosis en las plantas.

4. En cuanto a la inhibición a germinar ${ }_{j}$ el mejor tratamiento con la hidrazina resultó ser el que se aplicó al 0.25 por ciento, 4 semanas antes de la cosecha.

5. Sin tomar en cuenta el grado de concentración de la hidrazina ni la época de su aplicación, el porciento de germinación de la papa fué significativamente menor a una temperatura de $45^{\circ} \mathrm{F}$. que a los $68^{\circ} \mathrm{F}$.

\section{LITERATURE CITED}

1. Barnard, E. E., and Warden, R. L., The effect of various herbicides on weed control, stand, and yields of Netted Gem potatoes, North Weed Control Conference, p. $145,1950$.

2. Craft, A. S., et al., Response of several crop plants and weeds to maleic hydrazide, Hilgardia 20 57-80, 1950.

3. Denisen, E. L., Response of Kennebec potato to maleic hydrazide, Amer. Soc. Hort. Sc. 62 411-21, 1953.

4. Ellison, J. H. AND Smith, O., Effects of spraying a sprout inhibitor on potato plants in the field, Amer. Soc. Hort. Sc. $51397-400,1948$.

5. Greulach, V. A., The effect of maleic hydrazide on tomato plants in relation to their age at the time of treatment, Pl. Physiol. 26 848-52, 1951.

6. Mikkelsen, D. S., Griffith, R. B., and Ririe, D., Sugar beet response to maleic hydrazide treatment. Agron. J. 44 (10) 533-36, 1952.

7. Rodríguez, J. Pastor, La variedad de papa Kennebec no se enferma y produce altos rendimientos. Información Oficial Núm. 10, Estación Experimental Agrícola, Río Piedras, 1954.

8. Wittwer, S. H., and Paterson, D. R., Inhibition of sprouting and reduction of storage loses of onions, potatoes, sugar beets, and vegetable root crops by spraying plants in the field with maleic hydrazide, Mich. Agr. Exp. Station. Quart. Bul. 34 3-8, 1951. 